\title{
Do Higher Tax Rates Encourage/Discourage Tax Compliance?
}

\author{
María Jesús Freire-Serén ${ }^{1}$, Judith Panadés ${ }^{2}$ \\ ${ }^{1}$ Dpto. Fundamentos Análisis Ec. y GRiEE, Universidad de Vigo, Vigo, Spain \\ ${ }^{2}$ Dpto. d'Economia i Història Econòmica, Universitat Autònoma de Barcelona, Barcelona, Spain \\ Email: mjfreire@uvigo.es, judith.panades@uab.es
}

Received October 17, 2013; revised November 17, 2013; accepted November 24, 2013

Copyright (C 2013 María Jesús Freire-Serén, Judith Panadés. This is an open access article distributed under the Creative Commons Attribution License, which permits unrestricted use, distribution, and reproduction in any medium, provided the original work is properly cited. In accordance of the Creative Commons Attribution License all Copyrights (C) 2013 are reserved for SCIRP and the owner of the intellectual property María Jesús Freire-Serén, Judith Panadés. All Copyright (C) 2013 are guarded by low and by SCIRP as a guardian.

\begin{abstract}
In this survey, we try to summarize what economists know about how increasing tax rate affects both tax evasion and the willingness to pay taxes. We show how this apparently trivial question presents puzzling results. This paper introduces the main contributions that have attempted to explain the apparent contradiction between the empirical evidence on the reaction of taxpayers to changes in tax rate levels and the results obtained by the standard models of tax evasion. In an effort to shed some light on this issue, the paper primarily concludes that there is more than enough room for further research on the relationship between tax evasion and tax rates given the many gaps in the literature concerning on this topic.
\end{abstract}

Keywords: Tax Evasion; Tax Non-Compliance; Tax Rate

\section{Introduction}

The need to reduce the short-term budget deficits of some depressed developed economies has put pressure on these economies to conduct hard and austere plans of fiscal consolidation. For the most part, these measures focus on reducing government spending. However, the economic recession and an increasing unemployment rate have not only generated more expenditures such as the payment of unemployment benefit, but also generated the fact that the unemployed do not pay taxes, which has also caused a dramatic drop in public revenue. To recoup this lost revenue, governments have included measures aiming at increasing the tax burden in their austerity plans.

Detractors of this rising tax burden argue that this policy will decrease short-run economic activity (through demand side-effects) and/or long-run GDP (through supply side-effects). Moreover, the magnitude of some indirect effects remains to be seen. This in itself has triggered a large open debate on the convenience of implementing these kinds of fiscal policies. One of these indirect effects concerns the tax evasion phenomenon. Most of the tax systems in developed countries are not immune to the fact that taxpayers try to reduce their fiscal burden using both legal and illegal strategies.

According to the estimates of [1], the size of the shadow economy in countries like Mexico, Peru, Guatemala and Panama fluctuated between $40 \%$ and 60\% of GDP over the period 1990-1993. In European countries, this percentage decreases substantially but remains significant and disconcerting. For example in Spain, Italy, Portugal and Greece, this percentage was between 24\% and $30 \%$ of GDP ten years ago. The phenomenon of tax evasion is present even in countries with a consolidated fiscal system like the US. According to the Internal Revenue Service (IRS), the percentage of tax evasion on income in the US was around $16 \%$ in 2006 . Although the available data on the magnitude of tax evasion are mere estimates, it is obvious that this phenomenon should not be regarded as marginal; every year it takes away significant amounts of government revenues.

It seems plausible to think that tax evasion (and/or corruption) has made the economic crisis worse in some European countries since tax evasion limits the capacity of governments to raise revenues. Furthermore, the presence of tax evasion tends to make taxpayers wary of the government and consequently less willing to pay taxes. 
The report about combating tax fraud and evasion (Commission contribution to the European Council of 22 May 2013) states that: "The fight against tax fraud and evasion is important both for the protection of national budget revenues and for the confidence of citizens in the fairness and effectiveness of tax systems". Hence, one of the main points in the political agenda of developed countries should be to tackle and fight against tax evasion.

Nevertheless, in order to determine how tax evasion could distort the fiscal measures, we want to analyze whether higher tax rates encourage or discourage tax evasion. Governments decide to increase tax rates because they expect to achieve higher revenues which may in turn allow them to balance their public deficits. If taxpayers react to this tax increase by reducing their willingness to pay taxes and determination to declare a lower level of income, government revenues do not increase as expected. Therefore, the austere fiscal policies planned and implemented by the government will not produce the desirable outcome. The main goal of this article is to try to shed some light on how a tax rate increase may affect the tax evasion phenomenon.

Several empirical studies have documented that higher tax rates tend to stimulate tax evasion. However, from a theoretical point of view, the relationship between the tax rate level and the amount of evaded income is one question that has not been satisfactorily resolved as of yet. This controversy started in the 70's and continues to date, since most of the theoretical models predict that reported income increases as the tax rate increases. That is, increasing tax rates discourages tax evasion.

In this survey, we present the main contributions that attempt to explain the apparent contradiction between the empirical evidence on the reaction of taxpayers to changes in tax rate levels, and the results obtained by the standard models of tax evasion. Section 2 presents the standard model of tax evasion introduced by Allingham and Sandmo in [2]. Section 3 shows the empirical findings on the relationship between tax rates and tax evasion. Most of these papers show a positive relationship but some studies question the robusticity of this result and propose alternative models that aim to explain the puzzling empirical and theoretical findings. Section 4 revises the theoretical papers that try to explain the apparent contradiction between the standard model in [2] and the empirical evidence. Finally, Sections 5 and 6 conclude that the relationship between tax rate and tax evasion is still ambiguous. Section 5 also proposes some measures aiming at mitigating the negative effects triggered by the tax evasion phenomenon.

\section{The Allingham and Sandmo and the Yitzhaki Model}

Allingham and Sandmo presented in [2] the first attempt to theoretically analyze the behaviour of the tax evasion phenomenon. They study the individual tax evasion problem through a portfolio selection approach. In their model, the taxpayer maximizes expected utility, weighing the benefits of hiding income and remaining undiscovered, with the possibility of being caught and paying the corresponding fine. The likelihood of inspection and the penalty, in case taxpayers are caught, are key elements in determining the optimal amount of income they are to declare.

The main result of this seminal paper shows that under the plausible assumption of decreasing absolute risk aversion (DARA), the sign of the relationship between the amount of reported income and the tax rate is ambiguous when the fine paid by an audited evader is proportional to the amount of unreported income. This ambiguity comes from the co-existence of two effects: the income and the substitution effect. On the one hand, the substitution effect tells us that when the penalty for evading is proportional to the amount of evaded income and given a level of declared income, a tax rate increase does not modify the value of the penalty that taxpayers must pay if inspected. This effect generates incentives to substitute evasion for honesty. On the other hand, the income effect tells us that the taxpayers are getting poorer because they must pay more taxes for the same amount of declared income. Specifically, this effect is positive under the assumption DARA. In reducing richness, absolute risk aversion increases and, therefore, the taxpayer tend to reduce evasion in order to lower the risk of exposure.

Yitzhaki in [3] considered the Allingham-Sandmo static economy (A-S) where the penalties were proportional to the amount of evaded taxes instead of the amount of evaded income. This modification makes the original A-S model more realistic since tax legislations of developed countries tend to implement these kinds of fine schemes. Nevertheless, this new element generates an unambiguous result which runs in the opposite direction of general empirical evidence. Concretely, Yitzhaki shows that in this new scenario the substitution effect disappears given that an increase in the tax rate implies a rise in the penalty that the taxpayer must pay if caught and, thus, there is no incentive to substitute evasion for honesty. Under the assumption of DARA, the income effect runs in the same direction as the A-S model; therefore, an increase in the tax rate provokes an increase in reported income. As we mentioned before, this unambiguous result is at odds with the empirical evidence. Several studies suggest that higher tax rates tend to stimulate tax evasion. The next section presents the most significant empirical articles concerning the tax evasion phenomenon. 


\section{Empirical Findings}

Before presenting the results of the empirical research, we have to highlight how difficult it is for researchers to get accurate data on tax compliance. Note that tax evasion is an illegal and shadow activity and its undercover nature makes it very hard to obtain reliable data. Researchers must, therefore, consider different approaches to measure it. The traditional approach is to use information from audits, from tax amnesty data or from questionnaires in which taxpayers are asked about their non-compliance behaviour ${ }^{1}$. The papers presented here come from this empirical literature. But there is some recent literature that uses experimental economies to measure and analyze evasion behaviour ${ }^{2}$. At the end of this section, we will merely take a glance at a few contributions on tax evasion that come from experimental evidence.

A pioneering work in the traditional empirical literature on tax evasion was that of [7]. In the later paper, Clotfelter used 47,000 observations for 1969, provided by the US "Internal Revenue Service's Taxpayer Compliance Program”. Clotfelter took as a measure of tax compliance the logarithm of evaded income in three different taxpayer groups, according to the source of their income. Moreover, he included variables such as age, marital status, fiscal residence of taxpayers and other sources of income. The estimations suggested that higher marginal tax rates had a significant impact on the amount of detected evasion. The results were conclusive because in the three groups of taxpayers considered, the variable marginal tax rate positively affected the dependent evaded income variable. Specifically, elasticity values ranged from 0.515 to 0.844 . This means that when taking a value for the marginal tax rate of 0.40 , a decrease of $10 \%$ of this value (becoming 0.36 ) results in an expected decline of evasion which can vary between $5 \%$ and $8 \%$. Undoubtedly, these results are clearly consistent with the intuition that higher tax rates will encourage tax evasion.

Nourzad and Crane have contributed extensively to this literature with three important contributions [8-10], in which empirical results are consistent with [7] since a higher tax rate leads to higher levels of tax evasion. The first work [8] analyzes the problem of tax evasion from a theoretical point of view by incorporating the interest rate in the A-S model with penalties in Yitzhaki. In this context, the introduction of the interest rate does not change the result originally obtained by Yitzhaki, since an increase in the tax rate also results in a lower evasion. To carry out the empirical analysis they used aggregate time series data. They analyzed how the proportion of evaded income was affected by variables like the probability of auditing, the penalty (proportional to the

\footnotetext{
${ }^{1}$ See $[1,4,5]$ to know more about measuring tax evasion.

${ }^{2}$ See in [6] the discussion on approaches to measure tax evasion.
}

amount of taxes evaded), the tax rate, real income, inflation and interest rate. The results revealed a clear positive relationship between evaded income and tax rate. The authors suggest that a possible explanation for the contradiction between the theoretical and the empirical results may be the fact that the model considers a linear tax function while the data comes from a progressive tax system. With a progressive tax function, changes in tax rates affect both savings and consumption decisions, and generate an income effect as well as a substitution effect. So, if the substitution effect dominates the income effect, higher tax rates will also increase evasion.

Later on, reference [9] analyzed the effect of tax rates on tax evasion by using aggregate US data for the period 1941-1981. The study focused on the importance of variable inflation. It seems clear that inflation can affect the decision to evade. Inflation erodes the real value of nominal disposable income and this induces taxpayers to restore their purchasing power through tax evasion. Given the obvious difficulty of measuring tax evasion, the authors took as a tax evasion measure the difference between the Adjusted Gross Income (a proxy for accurate income) and the directly declared gross income to the Internal Revenue Service (IRS). This difference can be interpreted as an aggregate measure of evaded income and, therefore, it is also an indicator of the magnitude of tax evasion. Independent variables were the marginal tax rate, the probability of auditing, the penalty (as a proportion of evaded taxes), real income, institutional variables and a variable trend (since the analysis was performed with time series). The results are consistent with previous findings since higher marginal tax rates lead to greater tax evasion. In fact, estimates indicate that an increase in marginal tax rates not only increased the level of evasion but also increased the proportion of evaded income. This suggests that either the income effect had the same sign as the substitution effect, or the substitution effect clearly dominated the income effect.

Finally, reference [10] studies the impact of progressive tax functions in tax compliance. The analysis focused on establishing a difference between marginal and average tax rates and their effect on tax evasion since most current tax systems are progressive. Based on their previous work [8], they conducted two types of exercises. First they re-estimated the original regression by taking the same dependent variable and including some additional independent variables that might help explain the phenomenon of tax evasion. The obtained results reproduce the previous one: a higher marginal tax rate generated greater tax evasion. In a second step, they introduced the average tax rate as an explanatory variable. In this second regression, the marginal tax rate continued to have a positive impact on tax evasion. However, the average tax rate reflected a significant and negative rela- 
tionship with tax evasion. The intuition for this result is that the average tax rate solely generates an income effect because it only affects disposable income, while a change in the marginal tax rate also affects relative prices. The implication of such a result, in terms of fiscal policy, is clear. A marginal tax rate decrease is usually associated with a package of tax reforms that tend to increase the average rate to cater for the wish of governments to maintain their previous tax revenue ${ }^{3}$. The obtained results reveal that a reduction of the marginal tax rate and an increase in the average tax rate both tend to reduce tax evasion and therefore tax revenue could increase. Granted therefore that increasing the average rate is not strictly necessary to keep tax revenues constant, governments could relax the severity of their fiscal plans a little bit.

Also noteworthy in this literature is the contribution made by Poterba in [11], who studied the effect of marginal tax rates on tax compliance by analyzing time series of declared capital income between 1965 and 1982. The relevance of this exercise is to take as the dependent variable the percentage of declared income from capital gains, since this type of income is subject to less tax controls and thus, the tax evasion phenomenon could easily make its presence. Poterba cites revealing data: while the percentage of wage-declared income is $94.9 \%$, the compliance rate for capital gains is down to $64.3 \%$. He used two different variables to measure the marginal tax rate on capital gains: the maximum statutory tax rate for capital gains in the long term, and a weighted average marginal tax rate for capital gains over time. The regressions carried out also included a trend to cover the potential effects of inspection policy changes and other factors that might affect tax compliance. Poterba's results suggest, without any doubt, that marginal tax rate negatively affects the income declared. As an example, using the maximum statutory tax rate as a measure of marginal rate, Poterba found that if the marginal tax rate increases by $1 \%$, the reported income decreases at $0.4 \%$.

Alm et al. conducted in [12] an ambitious empirical study aimed at investigating how tax compliance is affected by variables like deductions on salary income, tax rates, the probability of inspection and penalties. The novelty of this work is the use of the term non-compliance tax in its broadest sense, i.e. including all activities both legal (avoidance) and illegal (evasion) that aim to reduce the tax burden of an individual. This study was based on the tax system in Jamaica during 1983, for which a very detailed database was available with information on the types of deductions workers could apply to reduce their tax burden. In this case, the dependent variables chosen were three folds: the proportion of total

\footnotetext{
${ }^{3}$ An example of this type of measure would be the elimination or reduction of deductions to taxpayers according to their personal characteristics.
}

compensation over declared gross income, the proportion of total compensation over deductions and, finally, the proportion of total compensation over evaded income. The independent variables were the marginal tax rate, the probability of inspection, the penalty (which was proportional to the amount of tax evaded) and other variables that quantified the importance of deductions from salary income. The results reinforced those mentioned above. Lower tax rates induced taxpayers to increase their level of tax compliance.

Pommerehne and Weck-Hannemann present in [13] an empirical investigation on aggregate tax evasion using data for 25 Swiss cantons throughout the course of several years. In view of the difficulty to accurately detect evaded income, the authors chose as the dependent variable a measure of discrepancy between declared income data provided by tax reports, and the income measured by national accounts. The independent variables were the marginal tax rate (the average of the marginal rates as the Swiss tax system is progressive), the probability of inspection, the fine (proportional to the amount of evaded tax), deductions, the percentage of unearned income, elderly taxpayers (since they could have more experience in tax issues) and a dummy. Running the regressions they obtained that the estimated coefficient of marginal tax rate was positive and significant, which again indicated the existence of a positive relationship between the tax rates and evaded income. Once more this result was consistent with previous empirical work. In a similar line, reference [14] used data from Germany to find evidence to suggest that higher tax rates tend to stimulate tax evasion.

Another interesting work is [15]. These authors examine the influence of taxes and subsidies on declared labour income. They use a sample of 3219 observations for the year 1988 in households classified as low income ${ }^{4}$. As in [7], the sample was divided into two types of occupations. This allowed for a better analysis of the determinants of tax compliance. The dependent variable was the mistakenly declared income, defined as the difference between the corrected wage income and declared wage income. Notice that this term means that the evasion phenomenon is understood either as declaring a lower income than the actual income or the phenomenon of over-declaration, i.e., declaring an income which is higher than what they actually earn. Independent variables included the probability of inspection, the marginal tax rate, income, marital status, age and a variable reflecting the origin of subsidies. The results are qualitatively consistent with those obtained by [7] since an increase in the marginal tax rate translates into evading a higher income. Still, reference [15] qualifies the effect of

${ }^{4}$ They use data from the "Taxpayer Compliance Measurement Program”. 
marginal tax rate on income evaded as moderate because, even though the estimated parameter value is positive, in some cases it is not significantly different from zero ${ }^{5}$.

Regarding this last comment, we must point out that although all of these empirical papers support the idea that a higher tax rate encourages evasion, some papers find an ambiguous relationship between tax rates and tax evasion. We will now present the two most well-known studies in this area. The first of them is the article [16] by Slemrod who, using US cross-sectional data for the year 1977, studied the relationship between tax evasion and variables like the marginal tax rate, real income, age and marital status. The results obtained on demographic variables are consistent with previous findings by other authors. Slemrod, however, could not confirm the positive correlation between marginal tax rates and evasion. His argument to support this claim was based on the fact that it was not possible to distinguish between the effect of an increase in the marginal rate and the increase of income on tax evasion. It was evident that simultaneous increases in the two variables had a positive effect on evasion but these two effects could not be separated.

The second study in [17] was conducted by Feinstein who used data from the Internal Revenue Service (IRS) in the US for the years 1982 and 1985. The dependent variable was the evaded net income. The independent variables were, among others, the marginal tax rate, real income, age, marital status, and the type of occupation. He estimated the two years separately and then deflated the 1985 data in order to express a third estimate for the total sample in 1982 dollars. The separate estimation of two years confirmed the positive relationship between avoidance and marginal rates. However, Feinstein was doubtful about this result because it is in fact very difficult to isolate the effect of the marginal tax rate on the evasion of total income effects. Instead, these two effects (the effect of marginal and income effect) could be identified by estimating the total sample. Note that the two observations with the same income marginal rates faced different if they were in different years. The results obtained in the estimation of this third model are clear and very significant: the marginal tax rate has a negative effect on evasion. In this case the theoretical result obtained by Yitzhaki is confirmed.

Let us finally take a look at experimental economy. Research presented in [18] used laboratory market experiments to find that higher taxes stimulate tax evasion. More recently, reference [19] performed a randomized tax enforcement experiment in Denmark. They discovered that marginal tax rates have a positive impact on tax evasion, but that this effect is small as compared to avoi-

\footnotetext{
${ }^{5}$ The authors emphasize that their results are only applicable to lowincome taxpayers and may not be extrapolated to higher-income taxpayers since they probably have greater opportunities to evade part of their income.
}

dance responses. However, we can also find some experimental evidence to the contrary. Thus contributions [20] and [21] found that higher tax rates have a negative impact on tax evasion 6 .

\section{Theoretical Results}

As of [3] there have been many authors who have sought to resolve the ambiguity posed by the traditional portfolio model with respect to the sign of the relationship between tax rate and tax evasion. All of them introduce new elements to enrich the original model and to obtain the expected result: that increases in tax rates lead to greater evasion. In line with this, reference [23] modified his previous model by assuming that the probability of being caught evading is an increasing function of the amount of undeclared income. In this context, he was able to show that an increase in the marginal tax rate encourages tax evasion.

An alternative research on tax evasion focused on the fact that chances for evasion differ among occupations and sectors. Reference [24] was the first to introduce a two-sector model, instead of the portfolio framework, to analyze the tax evasion problem. In his model, the economy has an evadable sector and a non-evadable sector. However, Watson's research yields ambiguous results. Without restrictions on absolute and relative risk aversion, it is impossible to predict how changes in tax rate will affect evasion. He is only able to prove that, given some conditions and under non-decreasing relative risk aversion, a rise in the tax rate will increase the proportion of tax evaders. Reference [25] proved that in the Watson model, under IARA (DARA) a rise in the tax rate increases (decreases) the number of workers in the evadable sector. Therefore, the odd results still yield ${ }^{7}$.

Back to the A-S portfolio benchmark, many papers have tried to generate that positive relationship through substantial departures from Yitzhaki's original model. These extensions add realism to the original model, but in general, the conclusions on the relationship between tax rates and compliance are not completely satisfactory. For instance, [26] introduced public goods in the original model to try to see the relationship between the provision of public goods and the payment of taxes by taxpayers. The public good is financed by the funds raised through taxes paid by taxpayers in an economy where these same taxpayers behave as evaders. The utility of individuals depends on their level of private consumption and the level of public good consumption. Thus, an increase in

\footnotetext{
${ }^{6}$ The experimental economy also has growing interest in tax evasion. See, for instance [22], who analyze how the changes in sanctions and detection enhancement produce an improvement in tax compliance yet they do not analyze the effect of changes in tax rates.

${ }^{7}$ These papers with multi-sector economy models are known as the literature on underground economy.
} 
the rate is linked to an increase in the amount of public good provided. Analyzing the economy under the assumption of DARA, they encounter the same odd result as Yitzhaki does when the marginal utility of private consumption is not affected by the level of public good. In contrast, when the marginal utility of private consumption is affected by the provision of public goods, their result is drastically different. They find that when the tax rate increases, so does the amount of tax evaded.

Although [26] presents results directed towards explaining the observed positive relationship between the tax rate and tax evasion, they cannot capture why nonevader behaviour prevails. To try to collect these effects, [27] appealed to the literature of "social norms" to find a reason to induce a loss of utility in evading taxpayers simply by performing the action to be evaded. Gordon called this effect the "psychological cost" of tax evasion and assumed that this grew as did the amount of income evaded. As allowed the assessment of this cost individual and subjective psychological out, taxpayers were divided into two types: evaders and avoiders. In this scenario a tax rate increase may lead a greater number of taxpayers to evade because the psychological cost of being an evader decreases as tax rates increase. However, the result obtained by [27] neither guarantees that individual evasion increases as the tax rate increases nor that aggregate evasion is greater than it was before.

In a new attempt to reconcile the theoretical and the empirical versions, contribution [28] proposed a twoperiod tax evasion model. In the first period each individual received an exogenous income. They decided how much they wanted to consume and how much they wanted to save. In the second period of life they only had income from their savings. Therefore, the taxpayer had to decide what fraction of the income from investment they would not declare to tax authorities. If detected, the taxpayer was fined proportional to the amount of tax evaded. The most important point of this paper refers to the likelihood of inspection. Klepper et al. modelled the frequency with which inspections were carried out as a function that basically depends on three variables: the fraction of capital income evaded, total evaded income and a variable measuring the characteristics that could affect the decision to evade. Results indicated that a higher tax rate discouraged savings and the proportion of evaded income was higher. The intuition of this result lies in the fact that if the tax rate increases, the savings is reduced while causing a reduction in the individual's income in the second period of his life. This result is contingent on the probability of inspection. So taxpayers obviously take advantage of this decrease in the risk of being audited and they increase the rate at which they evade their capital income.

Following this line of research, [29] builds a Ricardian framework where the tax evasion implications of an increase in the tax rate are independent of the crowding-out effect of public investment. To this end, Panadés also considers a two-period model. In the first period of life, individuals receive exogenous income that is subject to a proportional tax. Taxpayers maximize expected utility by choosing the level of declared income and the desired amount of saved income. If caught by tax authorities the taxpayer has to pay a fine proportional to the amount of income evaded. In their second period of life, individuals only receive the capital income accrued from their effective saving. Individuals face an exogenous probability of inspection. Moreover, they have to pay lump-sum taxes in both periods of life. In performing a standard Ricardian exercise, Panadés illustrates that if an increase in the tax rate takes place, taxpayers know that they will be compensated with a reduction in the lump-sum tax in their second period of life. Although the sign of the relationship between saving and the tax rate is ambiguous, the relationship between declared income and the tax rate is clearly consistent with the empirical results, since a higher tax rate leads to less declared income. The intuition of this result is based on the combination of the aforementioned substitution effect and income effect. A higher tax rate decreases the return to evade, since under DARA, lower income makes, via income effect, the evasion less attractive. However, a higher tax rate also has a substitution effect which reduces reported income. Yet an additional effect remains to be considered within this context: the compensation received by the individual via lump-sum tax in the second period of life. In this case, the compensation via lump-sum taxes overrides the income effect, so that it only survives the substitution effect. This allows us to conclude that if the tax rate increases, evasion will do so too. However, it should be noted, that when fines proportionate to the amount of tax evaded are taken, the results are totally opposite. That is, the results are identical to those of [3]: the relationship between tax evasion and tax rate is negative.

Reference [30] presents a modification of the A-S model which introduces the possibility of self-insurance against possible penalties if the taxpayer is audited. In this model the taxpayer maximizes expected utility by choosing the level of declared income and effort not to be discovered. The results show that the fact of being over-insured encourages individuals to take more risks or, equivalently, to avoid a larger amount of their income. So, in this context there are two opposite effects: on the one hand, the traditional income effect which appeared in the original model (positive) and, on the other, the effect associated to the ability of the taxpayer to insure against an inspection (negative sign). Consequently an increase (decrease) in the tax rate will lead to higher (lower) tax 
evasion if the impact of insurance is higher (lower) than the income effect.

Reference [31] departs from the standard A-S model by making taxpayer utility depend on their relative tax contribution. Thus, she introduces an equilibrium model in which the utility function of taxpayers depend both on the amount of their own individual consumption and their relative tax contribution. The analysis shows that an increase in the tax rate could induce taxpayers to raise the amount of unreported income when penalties are imposed on the amount of evaded taxes. This is so because individuals coordinate to report so low that declaring more income than the rest taxpayers, is heavily penalized. At this low-income report equilibrium, a tax rate increase results in more income being concealed from the tax authority.

Finally, another puzzling contribution comes from [32] who analyze how the rate of economic growth and the fraction of income declared by taxpayers vary with the tax rate. In this paper, they have shown that the negative theoretical relationship between unreported income and tax rates is preserved in a multi-period economy when fines are imposed on the amount of evaded taxes. However, under the assumption that the fine paid by caught evaders is proportional to the amount of evaded income, the sign of the previous relation is reversed.

Of course, there are more papers on tax evasion than those presented in this survey, but our aim here is to present the main papers attempting to respond to the question we pointed out. Thus, papers along this line that analyze other issues on tax compliance behaviour over the last decade are [33-35] among many others.

\section{Discussion and Final Remarks}

The motivation of this survey is to shed light on policy debates often claiming that a higher tax rate encourages evasion. We have shown that the theory does not provide a clear prediction. Paraphrasing Sandmo in [36]: "Is the existence of tax evasion an argument for a lower marginal tax rate? We have seen that the optimal tax analysis does not offer any clear conclusion on this point". Although most of the theoretical models predict that reported income increases with the tax rate, widely held empirical evidence runs in the opposite direction. Hence, most empirical studies support the idea that a higher tax rate encourages evasion, even though some papers are doubtful about this result.

When tax evasion is present, the effects of a raise in the tax rate on the tax revenue are not well defined Despite the fact that economic literature lacks a clear conclusion to this respect, we would like to give some recommendations to illustrate the potential distortion that tax evasion may produce to the expected effects of fiscal policy. Let us assume the most realistic framework, that is, taxpayer exhibits decreasing absolute risk aversion and the fines for evading are proportional to the evaded taxes $^{8}$. In this context, standard theoretical models predict that an increase in the tax rate will result in a higher declared income and hence an increase in tax revenues. On the contrary, empirical evidence shows that when the tax rate goes up taxpayers evade a higher amount of their income and this fact generates a negative effect on tax revenue. However, even if taxpayers behave according to the prediction of the empirical evidence, the negative effect of the tax evasion on the tax revenue does not overcome the positive effect of an increase in the tax rate. Therefore, the tax revenue will increase as the tax rate increases. We claim that governments have bear in mind that the consequences of their tax reforms could vary depending on the magnitude of tax evasion activities. More tax evasion could imply a lower increase in tax revenue when the tax rate rises.

The question that now arises is: What can governments do to reduce this negative effect on tax revenue consequent to the tax evasion phenomenon? The answer is far from straightforward, because there are pros and cons to the alternative measures that governments could put to use. One possible option would be to implement a fiscal system where taxpayers could choose to either pay a fixed amount of taxes set by the tax authorities and thus be exempt from tax inspection, or to only pay an amount chosen by taxpayers according to their declared income but be subject to a positive probability of being audited. These types of policies would effectively enable the government to collect the amount of taxes they had originally intended to collect. The main disadvantage of this option is that this type of fiscal system is less progressive than the current fiscal system (or maybe even regressive) and may leave the income distribution unimproved after taxes (or may even worsen it).

Governments could also implement a more severe tax enforcement policy to get rid of the incentives to evade. In this case, even if taxpayers reacted to an increase in the tax rate by evading more, the magnitude of the aforementioned negative effect on the tax revenue would be smaller and governments would be able to obtain more resources to mitigate the fiscal deficit issue. The main disadvantage of this option lies in the fact that, for example, an increase in the probability of inspection requires the allocation of more resources to pay for more inspectors.

\section{Conclusion}

Since the economic literature is not clearly conclusive

\footnotetext{
${ }^{8}$ Although the empirical evidence does not yield a conclusive result, it generally tends to support the assumption that the most tested hypotheses are the constant relative risk aversion hypothesis and the decreasing absolute risk aversion hypothesis.
} 
about the consequences of tax rate changes on tax evasion, it is evident that this topic still requires further research. As Alm declares in [6]: "My basic conclusion is a simple one: we have learned a lot in the last 40 years but there are still major gaps in our understanding. Indeed, we are still trying to answer many basic questions [...] Do higher tax rates encourage/discourage [tax] compliance?”

\section{Acknowledgements}

This research was made with financial support from the Spanish Economic and Competitivity Ministry through grants EC02011-23959 and ECO2012-32392. Support of the Xunta de Galicia and Generalitat of Catalonia through grants 10PXIB300177PR and SGR2009-00350 are also acknowledged.

\section{REFERENCES}

[1] F. Schneider and D. H. Enste, "Shadow Economies: Size, Causes, and Consequences,” Journal of Economic Literature, Vol. 38, No. 1, 2000, pp. 77-114. http://dx.doi.org/10.1257/jel.38.1.77

[2] M. Allingham and A. Sandmo, "Income Tax Evasion: A Theoretical Analysis,” Journal of Public Economics, Vol. 1, No. 3-4, 1972, pp. 323-338. http://dx.doi.org/10.1016/0047-2727(72)90010-2

[3] S. Yitzhaki, "A Note on Income Tax Evasion: A Theoretical Analysis,” Journal of Public Economics, Vol. 3, No. 2, 1974, pp. 201-202. http://dx.doi.org/10.1016/0047-2727(74)90037-1

[4] F. Schneider, "Shadow Economies around the World: What Do We Really Know?” European Journal of Political Economy, Vol. 21, No. 3, 2005, pp. 598-642. http://dx.doi.org/10.1016/j.ejpoleco.2004.10.002

[5] F. Schneider and D. H. Enste, "The Shadow Economy: An International Survey," Cambridge University Press, Cambridge, 2002.

[6] J. Alm, "Measuring, Explaining, and Controlling Tax Evasion: Lessons from Theory, Experiments, and Field Studies,” Tulane Economics W. P. 1213, 2013.

[7] C. Clotfelter, "Tax Evasion and Tax Rates: An Analysis of Individual Returns," Review of Economics and Statistics, Vol. 65, No. 3, 1983, pp. 363-373. http://dx.doi.org/10.2307/1924181

[8] S. Crane and F. Nourzad, “Time Value of Money and Income Tax Evasion under Risk-Averse Behavior: Theoretical Analysis and Empirical Evidence,” Public Finance/ Finances Publiques, Vol. 40, No. 3, 1985, pp. 381-393.

[9] S. Crane and F. Nourzad, "Inflation and Tax Evasion: An Empirical Analysis,” Review of Economics and Statistics, Vol. 68, No. 2, 1986, pp. 217-223. http://dx.doi.org/10.2307/1925500

[10] S. Crane and F. Nourzad, "On the Treatment of Income Tax Rates in Empirical Analysis of Tax Evasion,” Kyklos,
Vol. 40, No. 3, 1987, pp. 338-348. http://dx.doi.org/10.1111/j.1467-6435.1987.tb00684.x

[11] J. Poterba, “Tax Evasion and Capital Gains Taxation,” American Economic Review, Vol. 77, No. 2, 1987, pp. 234-239.

[12] J. Alm, R. Bahl and M. Murray, "Tax Structure and Tax Compliance," Review of Economics and Statistics, Vol. 72, No. 4, 1990, pp. 603-613. http://dx.doi.org/10.2307/2109600

[13] W. Pommerehne and H. Weck-Hannemann, "Tax Rates, Tax Administration and Income Tax Evasion in Switzerland,” Public Choice, Vol. 88, No. 1-2, 1996, pp. 161-170. http://dx.doi.org/10.1007/BF00130416

[14] O. Lang, K.-H. Nöhrbab and K. Stahl, “On Income Tax Avoidance: The Case of Germany," Journal of Public Economics, Vol. 66, No. 2, 1997, pp. 327-347. http://dx.doi.org/10.1016/S0047-2727(97)00033-9

[15] D. Joulfaian and M. Rider, “Tax Evasion in the Presence of Negative Income Tax Rates,” National Tax Journal, Vol. 49, No. 4, 1996, pp. 553-570.

[16] J. Slemrod, “An Empirical Test for Tax Evasion,” Review of Economics and Statistics, Vol. 67, No. 2, 1985, pp. 232-238. http://dx.doi.org/10.2307/1924722

[17] J. Feinstein, “An Econometric Model of Income Tax Evasion and Its Detection," RAND Journal of Economics, Vol. 22, No. 1, 1991, pp. 14-35. http://dx.doi.org/10.2307/2601005

[18] J. Alm, B. R. Jackson and M. McKee, "Estimating the Determinants of Taxpayer Compliance with Experimental Data," National Tax Journal, Vol. 45, No. 1, 1992, pp. 107-114.

[19] H. J. Kleven, M. B. Knudsen, C. T. Kreiner, S. Pedersen, and E. Saez, "Unwilling or Unable to Cheat? Evidence from a Tax Audit Experiment in Denmark," Econometrica, Vol. 79, No. 3, 2011, pp. 651-92. http://dx.doi.org/10.3982/ECTA9113

[20] J. Alm, I. Sanchez and A. de Juan, "Economic and Noneconomic Factors in Tax Compliance,” Kyklos, Vol. 48, No. 1, 1995, pp. 3-18.

[21] P. J. Beck, J. S. Davis and W. Jung, "Experimental Evidence on Taxpayer Reporting Behaviour,” The Accounting Review, Vol. 66, No. 3, 1991, pp. 535-558.

[22] G. S. Iyer, P. M. J. Reckers and D. L. Sanders, "Increasing Tax Compliance in Washington State: A Field Experiment,” National Tax Journal, Vol. 63, No. 1, 2010, pp. 7-32.

[23] S. Yitzhaki, "The Relation between Return and Income," The Quarterly Journal of Economics, Vol. 102, No. 1, 1987, pp. 77-95. http://dx.doi.org/10.2307/1884681

[24] H. Watson, “Tax Evasion and Labor Markets,” Journal of Public Economics, Vol. 27, No. 2, 1985, pp. 231-246. http://dx.doi.org/10.1016/0047-2727(85)90048-9

[25] Y. H. Jung, A. Snow and G. A. Trandel, "Tax Evasion and the Size of the Underground Economy," Journal of Public Economics, Vol. 54, No. 3, 1994, pp. 391-402. http://dx.doi.org/10.1016/0047-2727(94)90042-6

[26] F. Cowell and J. Gordon, "Unwillingness to Pay. Tax 
Evasion and Public Good Provision,” Journal of Public Economics, Vol. 36, No. 3, 1988, pp. 305-321. http://dx.doi.org/10.1016/0047-2727(88)90013-8

[27] J. Gordon, "Individual Morality and Reputation Costs as Deterrents to Tax Evasion,” European Economic Review, Vol. 33, No. 4, 1989, pp. 797-805. http://dx.doi.org/10.1016/0014-2921(89)90026-3

[28] S. Klepper, D. Nagin and S. Spurr, "Tax Rates, Tax Compliance, and the Reporting of Long-Term Capital Gains," Public Finance/Finances Publiques, Vol. 46, No. 2, 1991, pp. 236-251.

[29] J. Panadés, “Tax Evasion and Ricardian Equivalence," European Journal of Political Economy, Vol. 17, No. 4, 2001, pp. 799-815. http://dx.doi.org/10.1016/S0176-2680(01)00056-8

[30] K. Lee, “Tax Evasion and Self-Insurance,” Journal of Public Economics, Vol. 81, No. 1, 2001, pp. 73-81. http://dx.doi.org/10.1016/S0047-2727(00)00077-3

[31] J. Panadés, “Tax Evasion and Relative Tax Contribution,” Public Finance Review, Vol. 32, No. 2, 2004, pp. 183195. http://dx.doi.org/10.1177/1091142103261674
[32] J. Caballe and J. Panadés, "On the Relation between Tax Rates and Evasion in a Multi-period Economy," Hacienda Publica Española (Revista de Economía Pública), Vol. 183, No. 4, 2007, pp. 67-80.

[33] S. Dhami and A. al-Nowaihi, "Why Do People Pay Taxes? Prospect Theory versus Expected Utility Theory,” Journal of Economic Behavior and Organization, Vol. 64, No. 1, 2007, pp. 171-192. http://dx.doi.org/10.1016/j.jebo.2006.08.006

[34] J. Slemrod, "Cheating Ourselves: The Economics of Tax Evasion,” Journal of Economic Perspectives, Vol. 21, No. 1, 2007, pp. 25-48. http://dx.doi.org/10.1257/jep.21.1.25

[35] J. Slemrod and S. Yitzhaki, “Tax Avoidance, Evasion, and Administration,” In: A. J. Auerbach and M. Feldstein, Eds., Handbook of Public Economics, North Holland Publishers, 2002, pp. 1423-1470.

[36] Sandmo, "The Theory of Tax Evasion: A Retrospective View,” National Tax Journal, Vol. 58, No. 4, 2005, pp. 643-663. 